\title{
Academic freedom, the 'teacher exception', and the diminished professor
}

\author{
Frank Donoghue*
}

The Ohio State University, Department of English, 164 W. 17th Avenue, Columbus, Ohio 43210, USA

\begin{abstract}
This essay seeks to place the subject of academic freedom in the larger context of the management of the contemporary university. It does so first by reviewing the legal history of academic freedom, a narrative that reveals its steady erosion over the course of the twentieth and early twenty-first centuries. The second section of the essay explores incursions by university administrators into the ownership of teaching materials. Though it was long taken for granted that instructors owned the content of the courses they taught, the transformation of pedagogy through technology has changed that, as administrators can now monitor, control and indeed commodify the courses they offer. Taken together, the legal redefinition of academic freedom and the erosion of what used to be called the 'teacher exception' to the work-for-hire rule have turned universities into more manageable workplaces and university instructors into ordinary workers.
\end{abstract}

KEY WORDS: Academic freedom · 'Teacher exception' · Intellectual property · Online learning

\section{INTRODUCTION}

Perhaps no term is used with such veneration by university professors and at the same time is so misunderstood as 'academic freedom'. The term, as it is usually used, designates, if vaguely, a special kind of freedom of speech uniquely reserved for scholars and teachers in higher education. Yet, the institutional history of the concept reveals that it never existed in reality, and even as a rhetorical concept, academic freedom has steadily eroded since it was introduced in the USA in 1915. The legal history of academic freedom has only accelerated that erosion. This process has gone hand in hand with an equally steady erosion of the control that professors have over the materials they produce for the purposes of teaching. Intellectual property law has long held teachers exempt from the rules that apply to ordinary workers. That is, it is understood that if a factory worker creates a product while on the job, that product belongs to his or her employer. Since teachers create much of what they present in the classroom on their own time, US copyright law has for generations

${ }^{*}$ Corresponding author: donoghue.1@osu.edu recognized a 'teacher exception' to the work-for-hire rule. However, with the rise of the corporate university and the popularization of online instruction, the 'teacher exception' has come under fire in the US court system, where, recently, universities have consistently prevailed against professors.

This essay argues that the erosion of the concept of academic freedom and the gradual disappearance of the 'teacher exception' mirror each other, and that, taken together, they tell exactly the same story about the way the occupation of university professor is being redefined. That occupation is being diminished and degraded by university administrations so that universities themselves can be more manageable institutions, so that they can function even more like corporations than they currently do. It has been commonplace since the early 1990 s to refer to the 'managed university', but that term is often used quite abstractly (Martin 1998). In the pages that follow, I will try to show how universities are managed. In short, the process begins and ends with mechanisms that high-level administrators use to control their most essential employees: their instructors.

() The author 2015. Open Access under Creative Commons by Attribution Licence. Use, distribution and reproduction are unrestricted. Authors and original publication must be credited. 


\section{ACADEMIC FREEDOM}

As I have discussed in my article 'Why academic freedom doesn't matter' (Donoghue 2009), the concept of academic freedom was first introduced in the USA in an inspiring document issued by the American Association of University Professors (AAUP), founded in 1915. The Declaration of Principles was composed by a collection of professors who produced a document characteristic of the Progressive Era, exuding idealism and optimism. Every member of the AAUP's Committee on Academic Freedom taught at top-flight institutions: A. O. Lovejoy taught at Johns Hopkins, 9 were from Ivy League universities, and 4 were from flagship state universities (Wisconsin, California, Washington and Indiana). They were, for the most part, progressive social scientists: 3 economists (including the committee's chair, Edwin R. A. Seligman from Columbia), 2 political scientists, 2 sociologists, and a psychologist (plus an intellectual who defied classification, John Dewey). Their disciplines are significant because social scientists, as a result of the subjects they study, frequently make controversial assertions and thus attract scrutiny from administrators and the world at large. Finally, more than half of the committee had done graduate study in Germany-commonly regarded as the birthplace of academic freedom.

The result of this combination of largely Germantrained academics was the 1915 Declaration of Principles, a document that grants an unrealistic amount of power and liberty to professors. The idea driving this document is Lehrfreiheit, the freedom to teach and to inquire. As Walter Metzger explains it in a 1988 article, in the German tradition, and indeed in Prussian law, Lehrfreiheit was a 'limited privilege (it did not exempt professors from the civil service code, which demanded loyalty to the state, and it likewise held them accountable for their political and social behavior as private citizens)' (Metzger 1988, p. 12691270). Originally this right belonged only to full and associate professors. However, A. O. Lovejoy felt that a far more comprehensive definition was necessary. He convinced the other members of the committee to include all faculty and to broaden the horizon of its application. According to the 1915 Declaration of Principles, academic freedom would protect 'not just freedom to teach and inquire ... but also 'extramural freedom', by which it meant freedom to speak ... without the warranty of professional task or acknowledged expertise' (Metzger 1988, p. 1275).

The foundation of the AAUP's vision of academic freedom was its desire for professors to attain an important, authoritative role in society. The details of this re-imagination bear that out. The organization refused to think of the university as an 'ordinary business venture' and of academic teaching as 'a purely private employment'. Such thinking, they assert, 'manifests ... a radical failure to apprehend the nature of the social function discharged by the professional scholar' (Seligman \& Lovejoy 1915, p. 3). In its opinion, the scholar and the university related to one another in a way that is vastly different from a mere employee-employer relationship. The AAUP insisted that faculty are 'appointees' and not employees of the university, and that:

So far as the university teacher's independence of thought and utterance is concerned ... the relationship of professor to [university] trustees may be compared to that between judges of the Federal courts and the Executive who appoints them. University teachers should be assumed to be, with respect to the conclusions reached and expressed by them, no more subject to the control of the trustees than are judges subject to the control of the President with respect to their decisions (Seligman \& Lovejoy 1915, p. 4).

This analogy makes clear the value that the original AAUP members placed on academic freedom and the role of the scholar. This role is one of completely protected freedom; once appointed, a professor's speech and writing on any subject is immune to professional retribution. The fact that professors are explicitly compared to presidential judicial appointees drives home this point: they cannot be punished or dismissed for their opinions, no matter how unwelcome they may be to the universities that employ them. It is a distinctly different and stronger protection than that extended to ordinary citizens under the first amendment to the Constitution, which guarantees freedom of speech. Further, it commences immediately upon the professor's appointment.

Though the AAUP held a grand vision of the solemnity of academic freedom and the gravity of the role of the professor, the real working conditions of professors at the time were vastly different. In 1915, virtually all professors were employed on annual contracts. That is, they were not, in fact, appointed like federal judges. Eminent professors, such as the founders of the AAUP, would, of course, have had their contracts automatically renewed without question; yet, it is important to note that the AAUP was spurred into existence by notorious instances in which professors' employment contracts were not renewed.

College administrators, meanwhile, did not sit idly by while the AAUP declared the newly exalted and autonomous role of the professor. The American 
Association of Colleges (AAC; now the American Association of Colleges and Universities), also founded in 1915, consisting almost exclusively of college presidents, immediately set about arguing that the unrestrained freedoms bestowed on professors by the AAUP were unreasonable. The central counterargument of the AAC can be brutally paraphrased as follows: You professors want unlimited freedom of speech, but we're the ones who pay your salaries. So you have to make some concessions to us.

I can find no evidence that representatives of the 2 associations met in the ensuing years, but the nature of the concessions the AAC wanted are both prescient and carefully documented in that association's quarterly bulletins, particularly during the 1920s. The concessions they most adamantly demanded were (1) that there should be a probationary period of several years of employment to ensure that any professor is reliable and competent before he or she is granted the extraordinary privilege of academic freedom, and (2) that a professor's academic freedom should not extend beyond his or her field of scholarly expertise.

Both of these concessions are written into the AAUP's next major document, the 1940 Statement of Principles on Academic Freedom and Tenure (American Association of University Professors 1984). This is not a fiery manifesto, but rather a work agreement, an expression of reconciliation between professors and the college presidents who employ them. Yet, it has left in its wake a legacy of confusion. Most significantly, a great many academics who invoke the term 'academic freedom' are unwittingly referencing the broad definition of the 1915 Declaration of Principles, as opposed to the much narrower definition spelled out in the 1940 Statement of Principles, which is the governing document to this day. Many instructors of all ranks, that is, mistakenly assume that their freedom of expression is virtually unlimited, when in fact it is not. And while the Statement of Principles does recommend that academic freedom be extended to all ranks of instructors, it places considerable emphasis on the probationary period; that is, the period between a professor's initial appointment and the point at which he or she receives tenure. This is a particularly vexed issue in contemporary American academia, where only $33 \%$ of all instructors are either tenured or eligible for tenure (more about this at the conclusion of the essay).

The legal history of the term 'academic freedom' is equally misleading, albeit instructive. The term appears seriously in only a handful of high court rulings and pointedly in one significant lower court ruling. The timeline of academic freedom court cases cer- tainly bears comment, since it masks the connection between the 1940 Statement of Principles and subsequent court rhetoric. No one concerned themselves with academic freedom during World War II. Immediately after the war, suspicion, rising to the level of paranoia, about communism led to a repression of free speech in general in the USA, and at universities and in the entertainment industry in particular. There were no cases of note from 1940 through the peak of the McCarthy era. When in 1957 academic freedom finally did present itself before judges, it appeared as a strange and foreign concept, so foreign that when the US Supreme Court first discussed it, in Sweezy v. New Hampshire (1957) ${ }^{\mathbf{1}}$, Justice Felix Frankfurter resorted to a definition of the term that he found in a statement on academics in South Africa. In 1954, the New Hampshire attorney general's office subpoenaed Paul Sweezy and questioned him about his allegedly un-American activities. When Sweezy refused to answer all the questions, he was arrested for contempt. Although the case worked its way through the appeals process, reaching the US Supreme Court in 1957, and stands to this day as a landmark case in the legal history of academic freedom, Sweezy v. New Hampshire (1957) had nothing to do with academic freedom. Sweezy himself makes that clear; yet, the Court confuses the issue nevertheless (Donoghue 2009).

The case is replete with irony. Paul Sweezy had been an assistant professor of economics at Harvard, had published a book, The Theory of Capitalist Development: Principles of Marxian Political Economy, and was a self-proclaimed 'classical Marxist' (Sweezy 1942), but he would never go on to receive tenure. As anti-Communist sentiment rose sharply in the USA shortly after the conclusion of World War II, Sweezy, independently wealthy and likely realizing that he would not get tenure at Harvard, resigned his position in 1946. He proceeded to co-found, in 1949, the influential socialist magazine The Monthly Review. So, he was neither tenured nor even an academic when he was invited to deliver a guest lecture on the subject of communism at the University of New Hampshire in 1953, and thereby ran afoul of a newly passed state law aimed at thwarting subversive activities (Donoghue 2009).

From there, the events and the rhetoric only become stranger. Here is Sweezy's reason for not answering questions about the content of his (public!) lecture:

\footnotetext{
1 Sweezy v. New Hampshire (1957) 354 U.S. 234, 77 S. Ct. 1203, 1 L. Ed. 2d 1311
} 
I shall respectfully decline to answer questions concerning ideas, beliefs, and associations which could not possibly be pertinent to the matter here under inquiry and/or which seems to me to invade the freedoms guaranteed by the First Amendment to the United States Constitution.' (Sweezy v. New Hampshire 1957).

As an ordinary citizen, how could he possibly have sought refuge in the notion of academic freedom? He did not. He claimed that his right to freedom of speech was being compromised, and, by remaining silent after his arrest, he was duly convicted of contempt. Three years later, he found himself at the end of the appeals process, before the US Supreme Court.

In overturning the lower courts' decisions, however, the US Supreme Court swerves wildly from the facts of the case as well as Sweezy's own defense, and clearly echoes the rhetoric of the AAUP's 1915 Declaration of Principles (Seligman \& Lovejoy 1915). The Supreme Court makes the vague claim:

We believe that there unquestionably was an invasion of petitioner's liberties in the areas of academic freedom and political expression, areas in which government should be extremely reticent to tread (Sweezy v. New Hampshire 1957).

Sweezy never asked for that. The Court's elaboration on the importance of academic freedom is even more bizarre, extending the concept beyond professors (tenured or untenured) to students and putting the fate of our civilization in the balance:

The essentiality of freedom in the community of American universities is almost self-evident. No one should underestimate the vital role in a democracy that is played by those who guide and train our youth. To impose any strait jacket upon the intellectual leaders in our colleges and universities would imperil the future of our Nation ... Scholarship cannot flourish in an atmosphere of suspicion and distrust. Teachers and students must always remain free to inquire, to study and to evaluate, to gain new maturity and understanding; otherwise our civilization will stagnate and die (Sweezy v. New Hampshire 1957).

The dissonance between the Court's rhetoric and Sweezy's own understanding of what he was doing - deliberately impeding an investigation because he believed that that investigation was a threat to the First Amendment - is baffling. The only thing that makes Sweezy's lecture 'academic' is that he happened to deliver it at a university. He was no longer doing 'scholarship' at that point in his career. Yet, for reasons known only to the justices, the Supreme Court decided to turn his case into a referendum on academic freedom.

Just 16 years after the Sweezy decision a District Court and then an Appellate Court took a very dif- ferent view of the concept of academic freedom.

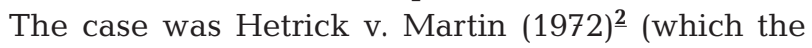
US Supreme Court unfortunately declined to hear). In 1973, Phyllis Hetrick's position was terminated by Eastern Kentucky University after just one year of service as an assistant professor. When she sued the university, she was informed that the reasons for her dismissal, never directly communicated to her, were (1) she, a divorced mother, made the inappropriate remark to one of her English composition classes that, 'I am an unwed mother'-presumably the statement was made to exhibit the irony and connotative quality of the English language; (2) Hetrick agreed to complete her PhD within her first semester at Eastern Kentucky, but the degree was not granted until her second semester; (3) her department chair expected that Hetrick would cover 20 plays in her Modern Drama course, but she only covered 11; and (4) Hetrick discussed 'with one of her sections of English Compositions the Vietnam War and the military draft' (Hetrick v. Martin 1973). I conjecture that Hetrick sued because it is obvious that all but the last of these charges are preposterously trivial, and that she was fired because of her views on the war, a violation of her academic freedom. Yet, both the District Court (Eastern Kentucky) and the Court of Appeals (Sixth Circuit Court) sided with Eastern Kentucky University. The District Court claimed that evaluating 'the wisdom of the university's decision not to renew the contract' was beyond the scope of the law. Its elaboration makes clear, though, that the duty of an assistant professor has nothing to do with freedom of thought or utterance, but rather with uncritical conformity to departmental policy:

It simply seems that Dr Hetrick's teaching methods were too progressive, or perhaps less orthodox than the other faculty members in her department felt were conducive to the achievement of the academic goals they espoused. The court must conclude that the State University has the authority to refuse to renew a nontenured professor's contract for the reason that the teaching methods of that professor do not conform with those of the tenured faculty or with those approved by the University (Hetrick v. Martin 1973).

The Court of Appeals uses the very same language, noting that:

Whatever may be the ultimate scope of the amorphous 'academic freedom' guaranteed to our Nation's teachers and students, it does not encompass the right of a nontenured teacher to have her teaching insulated from review by her superiors when they determine whether

\footnotetext{
$\underline{2}$ Hetrick v. Martin (1973) 480 F.2d 705 (6th Cir.)
} 
she has merited tenured status just because her methods or philosophy are considered acceptable within the teaching profession (Hetrick v. Martin 1973).

The District Court sidesteps the connection between academic freedom and the First Amendment, and instead concludes that:

the non-renewal of Dr. Hetrick's contract was ... based ... on the feeling that ... [her] teaching philosophy and the manner in which she implemented it were not adaptable to the achievement of the academic goals of the University (Hetrick v. Martin 1973).

The university judged her, in other words, simply as an employee and found her wanting. In doing so, they demonstrated how easily the provisions of the 1940 Statement of Principles could be circumvented. Note that the term 'academic freedom' is framed in quotation marks and characterized as 'amorphous' by the Court of Appeals. Thus, the Court not only rules in favor of Hetrick's employer, the University of Eastern Kentucky, on procedural grounds, but it goes further - challenging the very legitimacy of the concept of academic freedom itself.

That legal trend continues to this day. The most important recent case that touches on the subject, one that did reach the US Supreme Court, is Garcetti v. Ceballos (2006) ${ }^{3}$. The case, argued in 2005 and reargued in 2006, hinged on the degree to which a public employee has the right to freedom of speech while working. Richard Ceballos, a deputy district attorney in Los Angeles County, found major flaws in a police affidavit in a pending criminal case and pointed them out to his supervisors in a memo. As a result of his actions, he came to believe that he was 'subjected to a series of retaliatory employment actions', and ultimately sued his employers, claiming that his right to freedom of speech had been violated (Garcetti v. Ceballos 2006). His employers, in the name of Gil Garcetti, then District Attorney of Los Angeles County, countersued. While the lower courts ruled in favor of Ceballos, the US Supreme Court, in a 5 to 4 decision, reversed that decision. The majority opinion, written by Justice Anthony Kennedy, states plainly:

We reject ... the notion that the First Amendment shields from discipline the expressions employees make pursuant to their professional duties (Garcetti v. Ceballos 2006).

How are we to view this opinion in general, and how, more specifically, should we contextualize it as

\footnotetext{
3 Garcetti v. Ceballos (2006) 547 U.S. 410, 126 S. Ct. 1951, 164 L. Ed. 2d 689
}

a development in the legal theory of academic freedom? First, while the Supreme Court ruling acknowledges that this is delicate territory, and notes that employees must be safeguarded by existing 'whistleblower protection laws and labor codes - available to those who seek to expose wrongdoing' (Garcetti v. Ceballos 2006), it severely curtails guarantees of freedom of speech in the workplace in a way that tremendously empowers institutions rather than individuals.

The dissenting opinion, written by Justice John Paul Stevens, focuses on the question of whether an expert employee, such as Ceballos, is not exactly the kind of person who should be allowed to speak his mind on the job - even if his opinion may be unwelcome to his supervisors - because his freedom of speech serves the public interest. From there, Stevens makes the predictable move of worrying aloud about the safety of academic freedom, citing Sweezy v. New Hampshire (1957), and quoting the most melodramatic language from another landmark Supreme Court ruling - Keyishian v. Board of Regents of University of State of New York (1967) ${ }^{4}$ :

Our Nation is deeply committed to safeguarding academic freedom, which is a transcendent value to all of us and not merely to the teachers concerned. That freedom is therefore a special concern of the First Amendment, which does not tolerate laws that cast a pall of orthodoxy over the classroom. The vigilant protection of constitutional freedoms is nowhere more vital than in the community of American schools (Keyishian v. Board of Regents of University of State of New York 1967).

Yet, Kennedy, the author of the majority opinion notes this objection and responds, in effect, by saying nothing:

There is some argument that expression related to academic scholarship or classroom teaching implicates additional constitutional interests that are not fully accounted for in this Court's customary employeespeech jurisprudence. We need not, and for that reason do not, decide whether the analysis we conduct today would apply to a case involving speech related to scholarship or teaching (Keyishian v. Board of Regents of University of State of New York 1967).

The Court, in other words, elects to remain silent on the subject of academic freedom, an ominous sign, given that the sense and consequence of the ruling as a whole is precisely to 'cast a pall of orthodoxy' over all workplaces, and the rhetoric of its ruling is virtu-

\footnotetext{
${ }^{4}$ Keyishian v. Board of Regents of University of State of NY (1967) 385 U.S. 589, 87 S. Ct. 675, 17 L. Ed. 2d 629
} 
ally indistinguishable from that of the Circuit Court of Appeals in Hetrick v. Martin (1973), which held that Hetrick should have behaved like any other employee and simply conformed to the policies of her workplace, whether that workplace was a university or not (Hetrick v. Martin 1973).

It is a clear indication, I believe, that academic freedom, if it ever existed, no longer does - in fact, neither in rhetoric, nor in law. The legal history of academic freedom is thus a troubling one. It was never more than an unenforceable progressive fantasy concocted by the founders of the AAUP. However, at least it had champions on the US Supreme Court, justices who admired the idealistic notion that academia is a unique social institution, a special workplace in which freedom of expression is zealously safeguarded. This is a noble vision, but the trajectory of court decisions over the last half-century has been to reconceive of universities as no different from any other workplaces. This means that for instructors at universities, strict conformity to the rules of the workplace overrides freedom of expression. I can foresee a time when the lofty language of the 1915 Declaration of Principles ceases to appear even in the dissenting opinions of court rulings.

\section{THE 'TEACHER EXCEPTION’}

My broad argument is that the professional status of university professors has been significantly diminished, both in the system of higher education and in the legal system to which university administrators can always appeal. This development is clear if we examine the history of academic freedom, noting the occasions when it has actually been either respected or ignored. Bolstering that argument is a parallel development, even more easily tracked through legal history. The proprietary relationship between the materials used for the purposes of instruction and the teachers that create them has, in fact, an even longer and less ambiguous history than that of academic freedom: for generations there was no dispute over the fact that teachers own the content of what they taught. That principle was established in the USA in a precedent-setting case in 1909. The 'teacher exception' to the work-for-hire rule first became common law in the USA as a result of a ruling by the Supreme Court of the District of Columbia in the case of Sherrill v. Grieves (1909) ${ }^{5}$. Clarence Sherrill, an instructor at the United States Infantry Association,

${ }^{5}$ Sherrill v. Grieves (1929) 57 Wash. L. Rep. 286 composed a series of detailed lectures on military topography for his students. Those notes were then published, without Sherrill's permission, by the Association, with Loren Grieves named as the author. Sherrill sued the Association and won. The court ruled that it

... does not know of any authority holding that ... a professor is obliged to reduce his lectures to writing or if he does so that they become the property of the institution that employs him (Sherrill v. Grieves 1909).

In making this ruling, the court brushed aside the plaintiff's claim that Sherrill was compensated in the form of his salary, and that what he produced was thus work-for-hire.

This particular argument has subsequently been elaborated on many times, perhaps most eloquently by Judge Richard Posner, in his commentary on a much later case, Weinstein v. University of Illinois $(1987)^{6}$. He explains that although academics use their

... employer's paper, copier, secretarial staff, and (often) computer facilities as part of their employment, [a] college or university does not supervise its faculty in the preparation of academic books or articles, and is poorly equipped to exploit their writings, whether through publication or otherwise (Weinstein v. University of Illinois 1987).

The 'teacher exception' to the work-for-hire rule stood unchallenged for decades because no one saw the need to disturb it. In 1967, in Congressional hearings leading up to the revised Copyright Law of 1976, 9 experts on copyright law testified, and not one mentioned the 'teacher exception'. Elizabeth Townsend speculates that they may have believed it did not need to be mentioned (Townsend 2003). The court, in a case that slightly predates Weinstein v. University of Illinois (1987) - Williams v. Weisser (1969) ${ }^{7}$ - reflects a similar naiveté, stating that:

No reason has been suggested why a university would want to retain ownership of a professor's expressions ... Such retention would be useless (Williams v. Weisser 1969).

All of this has changed as higher education has become increasingly digital, and a curious bifurcation has taken place. Universities seem content to allow instructors to claim the profits of some of their

\footnotetext{
$\underline{6}$ Weinstein v. University of Illinois (1987) 811 F.2d 1091 (7th Cir.)

${ }^{7}$ Williams v. Weisser (1969) 273 Cal. App. 2d 726, 78 Cal. Rptr. 542 (Ct. App.)
} 
research-royalties and speaking fees, but not patents - as their own. Particularly in the world of online learning, institutions are increasingly aggressive about claiming proprietary rights over the content of courses because those courses are potentially a vast arena of profit. The current and intense legal debate about higher education thus revolves around the question of who owns teaching.

That problem is first of all logistical. When a course is taught online as opposed to face-to-face, the question of whether 'a professor is obliged to reduce his lectures to writing' becomes moot (Sherrill v. Grieves 1909). Everything about the course - syllabus, every lecture, supplementary content, quizzes and exams, essay prompts, grading rubrics - must, of necessity, be posted online in order for the course to be delivered to the students. Each of these items constitutes intellectual property of a very tangible kind. As Townsend (2003) puts it, 'works not economically valuable in an analog live-classroom may have great economic value in a digital age' (p. 225). She later elaborates: 'as the university becomes more commercialized, knowledge is commodified rather than individualized' (Townsend 2003, p. 244). She points out that Posner's observation in the late 1980s that a college or university is generally ill equipped to use the writings, specifically the writings for teaching purposes, such as class notes, no longer applies due to advances in technology (Townsend 2003). Universities are now very much in a position to exploit the writings that are incorporated into online teaching because they can track those writings so precisely and because they control the means by which those writings are delivered to students.

An online course, because it is a discrete entity, must belong to someone. Yet, once again, academics seem slow to grasp the consequences of the transformation from the amorphous face-to-face course to the replicable and therefore commodified digital course. This puts academics at a grave disadvantage. The most basic relationship in an online learning environment is between the university and the course management software company that the university hires to provide the technological platform for delivering the courses. In the USA, the largest of these is Blackboard, a publically traded corporation. In no way are instructors involved in these initial business transactions. In the vast majority of instances with which I am familiar, instructors simply fail to take these arrangements into account when they agree to teach online courses. Specifically, they fail to ask whether they own what they have agreed to teach. Does the 'teacher exception' apply, or are they essentially donating a 'course in a box' to their university, giving it the fruits of their intellectual labor without considering that the university may, at some future date, hand that ready-made course over to a lower-paid instructor?

Sadly, this widespread lack of vigilance will only diminish the amount of professional leverage that the teaching workforce has at universities. There is no question that online learning, already expanding rapidly, is poised to grow exponentially in the future at all kinds of colleges and universities. Jon Garon (2002, p. 148) explains that:

there may be little or no financial savings in the delivery of class content via the Internet ... The primary corporate savings are in scale - the ability to have the same materials viewed by hundreds of students instead of dozens - and efficiency, because the class can often be held at the student's office or work desk, rather than at an office location.

This means that all university instructors should be familiar with the concept and history of the 'teacher exception'. Yet, almost none are. All instructors of online courses should realize that, without a written contract, the course they are about to teach will belong to the university and not to them. Yet, almost no instructors request such a contract.

Two examples aptly illustrate my point that universities have already anticipated the legal means of shrinking the 'teacher exception' and the relative power that they may gain as a result, while professors have remained largely naive or unconcerned. The most recent relevant case involving the 'teacher exception' was heard in in 2010 in the District Court of Puerto Rico (Molinelli-Freytes v. University of Puerto Rico 2010) ${ }^{\underline{8}}$. In that case, Jose MolinelliFreytes et al. sued the University of Puerto Rico for alleged copyright infringement 'of original proposal for new graduate program in environmental studies that professors allegedly created during non-working hours while employed at the university.' The court ruled against the professors, citing but dismissing Posner's commentary. The conclusion of the Court's ruling is telling:

Thus, two decades from when Posner cited his concerns for preserving academic tradition by recognizing the 'teacher exception', this concern has already become de minimis as universities have proactively created policies that grant professors ownership of copyrights which the 'teacher exception' once ensured (MolinelliFreytes v. University of Puerto Rico 2010).

\footnotetext{
${ }^{8}$ Molinelli-Freytes v. University of Puerto Rico (2010) 727 F. Supp. 2d 60 (D.P.R. 2010)
} 
The policies that universities have proactively created are never articulated, but the rhetoric of the Court's decision should alarm any academic because the justices' decision to place 'teacher exception' in quotation marks is a rhetorical maneuver identical to the Appellate Court's decision to place 'academic freedom' in quotation marks in the case of Hetrick v. Martin. It strongly implies that the concept is amorphous and should be considered antiquated. In the Mollinelli-Freytes ruling, the Court essentially says that universities, not instructors, will determine the terms of ownership whenever professors teach. This is a chilling message.

More frightening still have been the consequences, for instructors, of the expansion in scale that makes online learning so profitable. When Garon made that observation in 2002, he could not have anticipated the emergence, less than a decade later, of the Massive Open Online Course (MOOC). In their purest format, MOOCs consist of a single professor, usually a superstar in his or her field, who exists only as a video presence in a series of taped lecturers which students can download and view at their convenience. The courses are free, the only supervision consists of a handful of teaching assistants, and assignments are peer-assessed. Further, the courses are enormous: Sebastian Thrun, a computer science professor at Stanford and the founder of Udacity, one of the major MOOC companies, taught a course on artificial intelligence that enrolled 100000 students.

MOOCs, however, can only survive if they can somehow find a way to become profitable, and the most sensible and efficient way for them to do this is to partner with traditional universities and offer online courses, on a grand scale, for academic credit. They have begun doing exactly that, setting up pilot programs with the California State University system, The Ohio State University, Duke University, and Georgia Tech, among others. More online courses means a need for more instructors, and this reintroduces the question of who owns the content of the courses that are to be offered. The major companies in the budding MOOC industry - Udacity, Coursera and EdX - are, based on the little evidence that is available, extremely aggressive about claiming exclusive intellectual property rights to the content of the courses taught by instructors they employ. A contract between Coursera and a university, which I obtained on condition of confidentiality, makes clear that the standard arrangement is likely to be one between the company and the university, in which the instructors surrender everything. Excerpts from the standard instructor's contract allow for no exceptions whatever.
The instructor must sign a document swearing that he or she

hereby irrevocably grant University the absolute right and permission to use, store, host, publicly broadcast, publicly display, publicly perform, distribute, reproduce and digitize any Content that I upload ... . To the extent that I create or develop any software, interfaces or assessment features for use in connection with the Course or the Platform. ... I hereby irrevocably grant University the right to use my contributions ... for any and all purposes.

The agreement concludes with absolute finality:

I certify and represent that I have read this Agreement, fully understand its meaning and effect, and have signed this Agreement intending to be legally bound. The provisions hereof shall be binding upon me and my successors, heirs and assigns.

If the culture of online teaching changes, and written contracts do become the norm, I fear that they will look like the contract above rather than like documents that preserve the 'teacher exception'. I believe that, while the concept of academic freedom is significant, it has rarely been understood in its historical context, particularly its legal context. Nor has it been viewed as part of a broader pattern, the most important component of which involves the question of who owns teaching. Once one analyzes that pattern, as I have begun to do here, placing the history of academic freedom side by side with the history of the 'teacher exception', one can then begin to understand the mechanisms by which higher administrations manage the contemporary university. Professors once constituted a unique class of workers. They had once enjoyed, as Stanley Aronowitz put it, 'The Last Good Job in America' (Aronowitz 1997). But now there are fewer of them than ever, and it is in the financial interests of universities to transform them into ordinary workers. That is exactly what they are doing.

Aronowitz's archly titled essay underscores the urgency of the issues I have tried to raise here. He describes his working life as one episode after another of almost comedic leisure:

What I enjoy most is the ability to procrastinate and control my own worktime, especially its pace: taking a walk in the middle of the day, reading between writing, listening to a $\mathrm{CD}$ or tape any time I want, calling up a friend for a chat (Aronowitz 1997).

A life-long advocate of labor organization, especially among the underprivileged in academia, Aronowitz's breezy tone is deliberate, employed because he does not believe he deserves the last good job in 
America, but rather that such jobs should be available to many more intellectuals employed in higher education.

Of course, fewer and fewer academic professionals enjoy anything like Aronowitz's working conditions. There are fewer and fewer each year with job security, control over the material they teach, and at least a semblance of power within the university. The sad reality is that legal proceedings over the last 2 generations have enforced on academia an erosion of academic freedom and an accelerated foreclosure of the 'teacher exception'. The teaching workforce at almost all kinds of colleges and universities has undergone a sea change. Now, the decisive majority of instruction at American universities is conducted by contingent faculty. These teachers have, in effect, already been reduced to the status of ordinary workers because they lack the leverage and security to become active participants in establishing university direction and governance.

The most reliable statistics, published by The Association of Governing Boards of Universities and Colleges, reveals that in 1969 a full $78 \%$ of all college and university teachers were either tenured or on the tenure track. Forty years later, in 2009, only 33.5\% are (Kezar \& Maxey 2013). The remainder are tenuously employed, and thus their ability to resist infringement of their academic freedom or to insist on fair compensation for, let alone ownership of, any online courses they teach, is severely compromised. No matter what they are called - and the nomenclature varies now that 'adjunct' has come to assume

Editorial responsibility: Stylianos Somarakis, Heraklion, Greece exclusively pejorative connotations (they are now more often called 'instructors,' or 'lecturers') - their academic employers can simply elect not to renew their contracts whenever they expire. Thus, ultimately, the prevailing exploitative labor practices, more so even than the legal machinations, may drive the further advancement of the managed university.

\section{LITERATURE CITED}

American Association of University Professors (1984) 1940 Statement of Principles on Academic Freedom and Tenure. AAUP Policy Documents and Reports, New York, NY

Aronowitz S (1997) The last good job in America. Soc Text 51:93-108

Donoghue F (2009) Why academic freedom doesn't matter. South Atl Q 108:601-621

Garon J (2002) The electronic jungle: the application of intellectual property law to distance education. Vanderbilt Journal of Entertainment Law and Practice 4:148-189

Kezar A, Maxey D (2013) The changing academic workforce. Trusteeship 21:15-21

Martin R (ed) (1998) Chalk lines: the politics of work in the managed university. Duke University Press, Durham, NC

Metzger WP (1988) Profession and constitution: two definitions of academic freedom in America. Tex Law Rev 66: 1265-1629

Seligman E, Lovejoy A (1915) AAUP 1915 declaration of principles. AAUP

Sweezy PM (1942) The theory of capitalist development: principles of Marxian political economy. Oxford University Press, New York, NY

Townsend E (2003) Legal and policy responses to the disappearing 'teacher exception', or copyright ownership in the 21st century university. Minn Intell Prop Rev 4: 209-283

Submitted: January 26, 2015; Accepted: July 20, 2015

Proofs received from author(s): September 14, 2015 